\title{
Turisták szállásfoglalási preferenciái - Hagyományos kereskedelmi szálláshelyek vagy Airbnb?'
}

\author{
Buda Gabriella - Lehota József \\ Szent István Egyetem
}

\begin{abstract}
A TANULMÁNY CÉLJA
A digitális forradalom hatására új társadalmi-gazdasági trendeket figyelhetünk meg, az egyik ilyen új jelenség a megosztáson alapuló gazdaság, amely a nemzetközi szakirodalomban sharing economy néven terjedt el. Ennek a peer-to-peer jellegü gazdasági modellnek az egyik emblematikus példája az Airbnb, amely mára az egyik legmeghatározóbb cég a szállásadási piacon, és komoly versenytársává vált a legnevesebb szállodaláncoknak is. Tanulmányunkban arra keressük a választ, hogy a fogyasztók, jelen esetben a Magyarországról külföldre utazó turisták mennyire ismerik, illetve mennyire nyitottak az Airbnb irányába, továbbá milyenek a fogyasztói preferenciáik.
\end{abstract}

\section{ALKALMAZOTT MÓDSZERTAN}

Online kérdöíves felmérésünkben 250 külföldre utazó magyar lakost kérdeztünk meg. A minta felülreprezentált budapesti, felsőfokú végzettséggel rendelkező nőkre. Az adatelemzés során a kereszttábla, korreláció és faktoranalízis módszerét alkalmaztuk.

\section{LEGFONTOSABB EREDMÉNYEK}

A külföldre utazó megkérdezettek 93\%-a már hallott az Airbnb-röl, és 42\%-uk már igénybe is vett Airbnb szolgáltatást, további 36\%-a a válaszadóknak nyitott a szolgáltatás igénybevételére. A múltbeli választás és a jövőbeli preferencia vizsgálat alapján megállapítottuk, hogy az Airbnb esetében a legmagasabb a lojalitási faktor. A jövőre vonatkozóan az apartmanok és a panziók eddigi igénybe vevői a legveszélyeztetettebb célszegmens, közel 50\%-uk a jövőben tervez Airbnb-t (is) igénybe venni, de a korábban szállodai szobát foglalók közül is közel $40 \%$ gondolkozik Airbnb-ben. További eredmény a fogyasztói attitüdöket tekintve, hogy az Airbnb-t az utazók leginkább a kedvező ár/érték arány, a több szobával rendelkezö, önálló lakás bérlése, illetve a főzési lehetőség miatt választják. A szállodákat ezzel szemben a biztonság, a kiszámíthatóság és a szállodai étteremben elérhető reggeli és vacsora miatt preferálják a legtöbben.

\section{GYAKORLATI JAVASLATOK}

További kutatásban érdemes vizsgálni, hogy mekkora fenyegetést jelent a fogyasztói preferenciák változása a hagyományos szálláshelyekre nézve, milyen mértékủ a verseny a különböző kereskedelmi szállástípusok és az Airbnb között, melyek azok a tényezők, amelyekkel a különböző szálláshely-típusok növelni tudják a fogyasztók lojalitását a saját irányukba.

Kulcsszavak: sharing economy, Airbnb, szálloda, fogyasztói attitüdök, turizmus

DOI: https://doi.org/10.15170/MM.2019.53.02.07

\footnotetext{
${ }^{1}$ A kutatás az Emberi Erőforrások Minisztériuma támogatásával, az Új Nemzeti Kiválóság Program keretében készült.
} 


\section{BEVEZETÉS}

Megosztáson alapuló közösségi gazdálkodás, együttmúködő fogyasztás, internetalapú közösségi gazdálkodás: a jelenség annyira újszerü, hogy a legtöbb esetben még nincs általánosan elfogadott magyar kifejezés a fenti gazdálkodási formák elnevezésére, a nemzetközi szakirodalomban a sharing economy kifejezés terjedt el. A digitális forradalom hatására új üzleti modellek alakultak ki az elmúlt évtizedben, illetve alakulnak ki napjainkban is, ennek egyik formája a megosztáson alapuló tevékenységek fejlödése digitális platformon keresztül. A téma újszerüségét mutatja, hogy egyre inkább terjed a megosztáson alapuló szolgáltatások ismertsége és igénybevétele szerte a világon. 2011-ben a Time magazin beválasztotta azon 10 ötlet közé, amelyek meg fogják változtatni a világot (Walsh 2011) A jelenséggel egyre gyakrabban találkozhatunk életünk hétköznapi tevékenységei során is. Egyrészt emberek meg tudják egymás között osztani lakásaikat, autóikat, háztartási eszközeiket, másrészt tudásukat, idejüket, élményeiket. Mivel mindezen dolgok megosztása jellemzően digitális platformon keresztül történik, ezért rendkívül sok ember kerül kapcsolatba egymással rövid időn belül, a kereslet és a kínálat is gyorsan egymásra talál, növelve a hatékonyságot.

Az egyik emblematikus példája a megosztáson alapuló gazdaságnak - ezen belül is a peer-to-peer típusú új üzleti modellnek - az Airbnb, amely alapvetően szállásmegosztó szolgáltatás. Az Airbnb-t három fiatal (Brian Chesky, Joe Gebbia, Nathan Blecharczyk) alapította 2008-ban San Francisco-ban. Az online piactér megalkotása és a nemzetközi terjeszkedést követően néhány éven belül olyan növekedést értek el a szállásmegosztó piacon, hogy a szállodaiparnak is szembe kellett néznie a fenyegetettséggel. Az Airbnb-t 2012-ben beválasztották az 50 leginnovatívabb vállalat közé, többek között az Apple, a Facebook, és a Google mellett (FastCompany 2012). 2018-ban már több, mint 6 millió ajánlat található az Airbnb kínálatában, mindez 191 országban, azon belül 81 ezer városban érhető el (Airbnb, 2019). Összehasonlításképp a Hilton 113 országban van jelen, 913 ezer szobával, és ráadásul mindezt 17 brand név alatt (Hilton
Worldwide Holdings, 2019). Az elmúlt években új irányokba is elmozdult az Airbnb, többek között luxus kivitelű szállásokra és a turistáknak adható élményszerü kínálatra is fókuszálnak különböző tematikus formákban (városnéző túrák, étel-italhoz kapcsolódó vendéglátás, különböző workshop-ok tartása, koncertek, stb.) Az élményekhez kapcsolódó ajánlatokra is komoly igény mutatkozik, jelenleg már több, mint 25 ezer különböző élményt kínálnak a helyiek a turistáknak (tudás és idő megosztás), több mint 1.000 városban (Airbnb 2019).

A tanulmány első részében bemutatjuk a sharing economy és ezen belül is az Airbnb-hez kapcsolódó tudományos munkák főbb irányait, illetve a szállásfoglalási piacon kialakult versenyhez kapcsolódó tudományos megállapításokat. A tanulmány második részében az ehhez a témához kapcsolódó, önálló kutatásunk eredményét mutatjuk be, többek között a külföldre rendszeresen utazó magyarországi lakosok szállásfoglaláshoz kapcsolódó szokásait és fogyasztói attitűdjeit, továbbá ezen utazók múltbeli szokásait, és a jövőre vonatkozó terveit is kutattuk.

\section{ELMÉLETI HÁTTÉR ÉS SZAK- IRODALOM FELDOLGOZÁS}

A megosztáson alapuló gazdaságnak jelentős számú elnevezése, definíciója és jellemzője van. A nemzetközi szakirodalomban is többféle elnevezéssel találkozhatunk: sharing economy, collaborative consumption, mesh economy, on-demand economy, access-based economy, collaborative economy, de leginkább a sharing economy terjedt el, mint átfogó kifejezés. Ezen elnevezések elsődleges forrását, illetve a magyar elnevezéseket, amelyeket a hazai szakirodalom is használ, az 1. táblázat mutatja be. 


\section{1. táblázat: Különböző elnevezések a megosztáson alapuló gazdaságra}

\begin{tabular}{|l|l|l|}
\hline angol elnevezés & magyar elnevezés & szerző(k) \\
\hline collaborative consumption & együttmüködő fogyasztás & Botsman - Rogers 2010 \\
\hline mesh economy & hálózati gazdaság & Gansky 2011 \\
\hline access-based consumption & hozzáférés alapú fogyasztás & Bardhi - Ekhard 2012 \\
\hline sharing economy & megosztáson alapuló gazdaság & Friedman 2013 \\
\hline on-demand service & igény alapú szolgáltatás & Frenket et al. 2015 \\
\hline collaborative economy & közösségi gazdaság & EB 2016 \\
\hline
\end{tabular}

Forrás: saját szerkesztés

A következőkben általános megnevezésnél a sharing economy-t fogjuk használni, vagy az általunk legmegfelelőbbnek tartott megosztáson alapuló gazdálkodást, mint a sharing economy hazai megfelelöjét. A hazai szakirodalomban többek között Dudás és Boros (2019) járta körül a sharing economy fogalmi kérdéseit, ők a közösségi gazdaságot használták átfogó kifejezésként a jelenség megnevezésére, illetve Jancsik és társai (2018) a megosztásgazdaság kifejezést preferálták. Munoz és Cohen (2017) összefoglalták a sharing economy-re vonatkozó föbb jellemzőket: platform-függőség, alulhasznosított eszközök, peer-to-peer tranzakciók, közösségi irányítás, misszió, alternatív finanszírozás, technológia-függőség. Korábbi tanulmányunkban kategorizáltuk az internetalapú közösségi gazdálkodás formáit, figyelembe vettük, hogy valóban megosztás történik-e vagy újraelosztás, milyen az üzleti modell típusa ( $\mathrm{C} 2 \mathrm{C}$ vagy $\mathrm{B} 2 \mathrm{C}$ vagy $\mathrm{C} 2 \mathrm{~B})$, milyen mértékú a monetizálás a részvevő felek között, valamint mi a megosztás tárgya (materiális vagy immateriális javak) (Buda - Lehota 2017).

Szállásmegosztás esetén az Airbnb jó példa a megosztáson alapuló gazdaság elemzésére. $\mathrm{Az}$ Airbnb vonatkozásában sok tudományos igényű cikk született az elmúlt időszakban, jelen tanulmányban azokra a kutatásokra fókuszálunk, amelyek az igénybe vevők fogyasztói magatartását, motivációit és attitüdjeit elemezték, valamint a szálláshelyek magánszálláshelyekkel való helyettesítésének okait kutatták. Több tanulmány bemutatja, hogy az ár, az élmény és az önálló lakás előnyei azok a tényezők (azaz alapvetően a praktikus előnyök), amelyek leginkább befolyásolják a döntést, és a bizalmatlanság a leginkább ismert korlátozó tényező (Kam Fung So et al. 2018, Guttentag et al. 2017). Az Amerikai Egyesült Államokban élő megkérdezettek nemcsak a gazdasági elönyöket, hanem a fenntarthatóságot és a közösséget is motivációs faktornak tekintik, míg a bizalom hiánya, a technológiával kapcsolatos tudáshiány, illetve a gazdasági előnyök feltételezett hiánya gátolja leginkább az embereket a használatban (Tussyadiah 2014). A teljeskörủ képhez hozzátartozik, hogy vannak tanulmányok, amelyek a fogyasztói attitűdöket vizsgálják az Airbnb irányába, függetlenül attól, hogy használják vagy nem az Airbnb-t. Az elmúlt években a média egyre többször közvetítette, hogy az Airbnb-nek számos negatív hatása van, az egyik leghangosabb az AHLA (American Hotel \& Lodging Association) nemzeti kampánya volt (Benner 2017). Ilyen negatív hatás lehet a szomszédok elégedetlensége, a turizmus és ezáltal zajszint megemelkedése, illetve a biztonság csökkenése. További elégedetlenségi faktor lehet a lakásbérleti díjak, a lakásárak emelkedése fogyasztói oldalról. Mody et al. (2018) kutatása alapján azonban a fogyasztók negatív érzelmei nem olyan erősek, mint ahogy azt a média beállítja.

Az elmúlt években az Airbnb jelentős növekedést ért el, kielégítve az egyre növekvő fogyasztói igényeket, és egyre inkább fellép a szállodai szobák helyettesitö szolgáltatásaként. Ezzel egy időben éles kritikák is megfogalmazódtak vele szemben, és a romboló hatását hangsúlyozzák a szállodaiparra (Mody et al. 2018). Guttentag és Smith (2017) tanulmánya szerint az Airbnb-t már használók 2/3-a a szállodák helyettesítéseként választotta az Airbnb-t, és kutatásuk szerint az Airbnb jobb minöségü a motelekhez képest, de nem éri el az előkelö szállodák színvonalát, azaz alapvetően a középkategóriás szállodák helyettesítőjeként lép fel. Zervas et al. (2017) az Amerikai Egyesült Államokban, azon belül Texasban vizsgálták az Airbnb hatását a szállodai iparág bevételeire. Eredményül azt kapták, hogy minden 10\%-os növekedés az Airbnb piac méretében $0,39 \%$-os csökkenést jelent a hotel 
szobák bevételeiben. Austinban, ahol az Airbnb jelenléte rendkívül gyorsan növekedett, 8-10\%-os negatív bevételi hatást becsültek a legsérülékenyebb szállodáknál (alacsonyabb ár-kategóriájú szállodák).

Az Airbnb múltjáról, jelenéről és jövőjéről publikált tanulmány szerint (Mody and Gomez 2018) a múltban a szállodák még nem tekintették versenytársnak az Airbnb-t, és az Airbnb is úgy fogalmazott, hogy nem azonos a célközönsége a szállodáknak és a lakásmegosztásnak. Ez azonban változott, jelenleg már komoly versenytársként tekint a szállodaipar az Airbnb-re, és a küzdelem középpontjában az áll, hogy a szállodák vagy az Airbnb érti-e meg jobban a fogyasztók kívánságait. Új társadalmi trendeket figyelhetünk meg: egyre nagyobb igény van az egyedi, autentikus tapasztalatokra, megfigyelhető a globális turizmus, fontos a személyre szabott ajánlat és az élménygyüjtés, valamint közösségi lét. A jövőre vonatkozóan pedig már egyértelműen kijelenthetjük, hogy a szállodaiparnak fel kell vennie a versenyt az Airbnb-vel, és újra kell gondolnia mind a brandépítést, mind az élménynyújtás kérdését. A közelmúlt kutatása azt mutatja Mody és Gomez tanulmánya szerint (2018), hogy az Airbnb nagyobb márkahüséget generál, mint egy-egy szállodához tartozó márka. Érdekességképp az Airbnb autentikus, helyi élményekkel hirdeti magát, de a legtöbb turista elsősorban nem emiatt, hanem az ár és az elegendő élettér miatt választja ezt a szállásfoglalási lehetőséget (Dogru \& Pekin 2017). A személyre szabott ajánlat kínálata olyan jól sikerült, hogy a mikro-szegmentálás következményeként valóban létrejön a tökéletes egymásra találás a szállást kereső és a szállást adó között (Dolnicar 2018).

Magyarországon engedélyezett az Airbnb, és a magyarországi lakosok külföldi utazásiak során is igénybe tudnak venni Airbnb szolgáltatásokat sok országban. 2017-ben készült magyarországi, országos reprezentatív felmérés szerint az ország lakosságának mindössze 1,4\%-a használt már Airbnb-t, míg az ország lakosságának 37,3\%-a hallott már a szolgáltatásról. Azon válaszadók közül, akik már hallottak a szolgáltatásról, 47,3\%-uk nyitott a szolgáltatás igénybe vételére a jövöre vonatkozóan. Reprezentatív minta alapján, a kutatás eredményei szerint a férfiak, az aktív munkavállalók, a nem családosok, a fiatalabb generációk, a nagyvárosi, illetve a vagyonosabb emberek nyitottabbak a szállásmegosztó tevékenységek használatának irányába (Buda és tsai 2018).

A következőkben bemutatott kutatásunkban a magyarországi lakosok közül azon utazók szokásait, motivációit, szállásválasztási preferenciáit vizsgáltuk, akik rendszeresen utaznak külföldre.

\section{ANYAG ÉS MÓDSZER}

Célul tủztük ki, hogy a külföldre utazók szállásfoglalási preferenciáit megismerjük, különös tekintettel az Airbnb-re. Egy mélyinterjú sorozat után, és azon válaszokat alapul véve szerkesztettük meg az internetalapú online kérdőívet, amelyet hólabda módszerrel osztottunk meg elsőkörben baráti, ismerősi, illetve munkahelyi környezetben, továbbá egyetemi hallgatók körében.

A kérdőívben kizárólag olyan emberek válaszait értékeltük, akik rendszeresen járnak külföldre. Ezen feltételt figyelembe véve 250 -en töltötték ki a kérdőívet 2019. februárjában. A válaszadók 68\%-a nő, míg $32 \%$-a férfi. Életkor tekintetében a válaszadók 28\%-a a Z generációhoz (16 és 25 év között), 23\%-a az Y generációhoz (26 és 39 év között), és 48\%-uk az X generációhoz tartozik (40 és 59 év között), a válaszadóknak mindössze $1 \%$-a tartozik a Babyboom generációhoz ( 60 év felett). A megkérdezettek iskolai végzettsége alapján elmondható, hogy a válaszadók $6,8 \%$-ának középiskolai végzettsége van, $22 \%$-uk jelenleg felsőoktatásban hallgató, $59 \%$-uknak föiskolai vagy egyetemi végzettsége van, és $12 \%$-uk posztgraduális fokozattal rendelkezik. Lakóhelyet tekintve a válaszadók $64 \%$-a Budapesten, 10\%-uk megyeszékhelyen, 20\%-uk városban és 6\%-uk faluban, községben él. Jövedelmi szintet tekintve a megkérdezettek $14 \%$-a nem válaszolt, 10\%-uknak nincs vagy átlag alatti a jövedelmük, 41\%-uknak átlagos, míg 35\%-uknak átlag feletti jövedelmük van. A válaszadók eloszlásából látszik, hogy a minta nem reprezentatív, azaz a megállapításainkat ezen korláttal tudjuk megtenni.

A fogyasztók szállásfoglalási magatartásánál vizsgáltuk, hogy a külföldre utazó válaszadók milyen gyakorisággal és kikkel utaznak, jellemzően milyen módon foglalnak szállást. Az Airbnb megjelenése egy új trend a szállásfoglalási piacon, ezért a meglévő szokásokon túl a jövőbeli preferenciákat is vizsgáltuk. Felmértük, hogy mennyien hallottak már az Airbnb-röl, és ezek után le is írtuk a jelentését, hogy a későbbi válaszadások során mindenki azonos információszinten legyen. Vizsgáltuk az Airbnb-hez való hozzáállás attitüdjét, az elzárkózók között kutattuk az elzárkózás okait. Az Airbnb szállások között is többféle szállást különböztetünk meg, a válaszadóknak lehetősége volt preferenciáik alapján választani (apartmannak kialakított önálló lakás bérlése; olyan lakás bérlése, ahol egyébként laknak, csak a szálláskiadás idejére kiköltöznek az ottlakók; szoba bérlés, azaz a kiadóval egy lakásban van a szállás).

Ezek után vizsgáltuk, hogy a külföldre utazók milyen típusú szállásokat foglaltak az elmúlt években, és a jövőre vonatkozóan 
milyen preferenciáik vannak. Szállástípusok megkülönböztetése: három-, négy- és ötcsillagos szálloda, panzió, apartmanház, kemping, Airbnb típusú szállások. A jövőre vonatkozó terveknél megkülönböztettünk nagyvárosi szállásfoglalást, illetve a vízparti turizmuson belüli szállásválasztást. Ezek után fogyasztói preferenciákat vizsgáltunk mind a szállodai, mind az Airbnb szolgáltatásokra vonatkozóan 5 fokozatú Likert skálán. Különböző fogyasztói preferenciákat soroltunk fel, és ennek alapján vizsgáltuk, hogy mely tényezők miatt preferálják az utazók az Airbnb-t, ill. mely tényezők alapján a szállodai szolgáltatásokat. Tervezett célunk volt, hogy a két preferencia vizsgálat eredményét együttesen is vizsgáljuk kereszttáblás módszerrel, illetve faktoranalízissel.

További kutatási pontként vizsgáltuk a következőt: Airbnb esetén elterjedt vélemény, hogy kedvező ár/érték arányban lehet lakást/szobát bérelni. Ezen nézetet alapul véve vizsgáltuk, hogy az emberek mekkora része választaná az Airbnb-t megtakarítás céljából, és mekkora részük nem a megtakarítási szempontot helyezi előtérbe, hanem a szállásra szánt összeget szeretné a számára legmegfelelőbb módon elkölteni, és ezért Airbnb ajánlásokat is figyelembe vesz a szálláskeresésénél. Végezetül az élményszerủ városnézésre, helyi emberek megismerésére vonatkozó nyitottságot vizsgáltuk, mely egyre népszerübb az utazók között és egy teljesen újszerü megközelítése a helyi sajátosságok bemutatásának.

\section{EREDMÉNYEK}

A válaszadók mintája felülreprezentált a budapesti, felsőfokú végzettséggel rendelkező nők körében, az eredményeket ezen korlátokkal tudjuk megtenni. A válaszadók $44 \%$-a évente egyszer-kétszer, míg az 56\%-uk évente többször is utazik külföldre. A válaszadók jellemzően családdal (71\%), és/vagy baráttal/barátnővel és/vagy házastárssal utaznak külföldre (44\%), de előfordul, hogy kisebb-nagyobb baráti társasággal (45\%). Szállást jellemzően a booking.com-on foglalnak az emberek $(81 \%)$, de az emberek 42\%-a már az Airbnb.com-ot is használt. A válaszadók 33\%-a a szálláshely weboldalán, illetve Facebook oldalán is szokott szállást foglalni, a telefonos foglalás viszont már egyre ritkább (6,6\%). A külföldre utazók 15\%-a utazási irodán keresztül (is) szokott szállást foglalni.

Airbnb-röl a válaszadók 93\%-a hallott már. Míg az országos reprezentatív mintában az emberek mindössze 1,4\%-a használta még csak az Airbnb-t (Buda et al. 2018), addig ebben a mintában, amely értelmiségi, budapesti, átlagos és átlag feletti jövedelemmel rendelkező nőkkel felülreprezentált minta, továbbá rendszeresen külföldre utazók válaszait értékeltük, már $42 \%$-uk igénybe is vette az Airbnb-t (1. ábra). A válaszadók további 36 \%nyitott a szolgáltatásra, és mindössze a válaszadók 22\%-a zárkózik el az Airbnb jellegủ szállásoktól. Külön kérdésként vizsgáltuk, hogy azon válaszadók között, akik elzárkóznak az Airbnb elöl, melyek a legfontosabb kizáró okok. Ennek alapján a legtöbben azt jelölték meg, hogy nem szeretik a váratlan meglepetéseket (38\%), és/vagy nem bíznak az Airbnb-ben (36\%), és/vagy egyszerüen jobban szeretik a szállodákat és a szállodai szolgáltatásokat (35\%). A fekete / szürkegazdaság iránti ellenérzés miatti visszautasítást az emberek mindössze $12 \%$-a jelölte meg, illetve az emberek 7\%-ának már volt rossz tapasztalata az Airbnb-vel, vagy rosszakat hallott róla, és ezért elutasító az Airbnb-vel szemben.

A szállásfoglalási szokások alapján a legtöbben apartman szállást vettek már igénybe $(67 \%)$, illetve három- és négycsillagos szállodát $(53 \%$, ill. 59\%). Az elmúlt években jellemző szállásfoglalási szokásokat mutatja az 1. diagram is. Látható, hogy sokan már igénybe vettek Airbnb-t, de azon belül is megoszlik, hogy mely típusú Airbnb szállást használták a legtöbben. Míg az önálló lakást a válaszadók $42 \%$-a használta már, addig a más által lakott lakást/szobát már csak a válaszadók kisebb része vette igénybe $(11$, ill. $10 \%)$. A válaszadás során több lehetőséget meg lehetett jelölni. 


\section{1. ábra: Külföldi szállásfoglalási szokások}

magyarországi utazók körében az elmúlt években, $\mathrm{N}=\mathbf{2 5 0}$

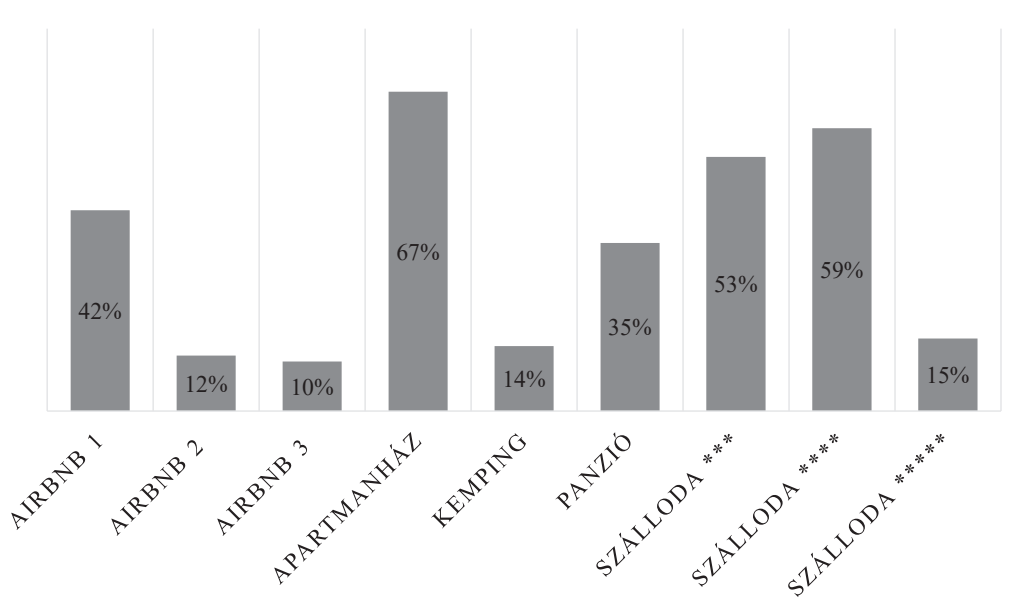

Forrás: saját szerkesztés

Magyarázat: Airbnb 1: apartmannak kialakitott lakás bérlése (pl. egy társasházban); Airbnb 2: olyan lakás bérlése - amelyben egyébként lakott valaki - de a bérlés idejére elköltözött; Airbnb 3: szobabérlés (a kiadóval egy lakásban szállás - couchsurfing jellegü).

A jövőre (a következő egy-két évre) vonatkozóan megkülönböztettük a nagyvárosi és a vízparti szállásra vonatkozó szállásválasztási preferenciát, hiszen más jellegü igények merülhetnek fel az utazás típusától függően. Nagyvárosi szállásfoglalásnál az Airbnb, valamint a három és négycsillagos szállodák választása volt a legmagasabb arányú, míg a vízparti helyeknél az apartmanházak a legkedveltebb szálláshelyek, utána jönnek a három, illetve négycsillagos szállodák, és ezután jön az Airbnb, ezeket az eredményeket a 2. ábra mutatja.

\section{2. ábra: A következő néhány évre vonatkozó szállásfoglalási preferencia nagyvárosi, illetve vízparti szállásfoglalás esetén, $\mathbf{N}=\mathbf{2 5 0}$}

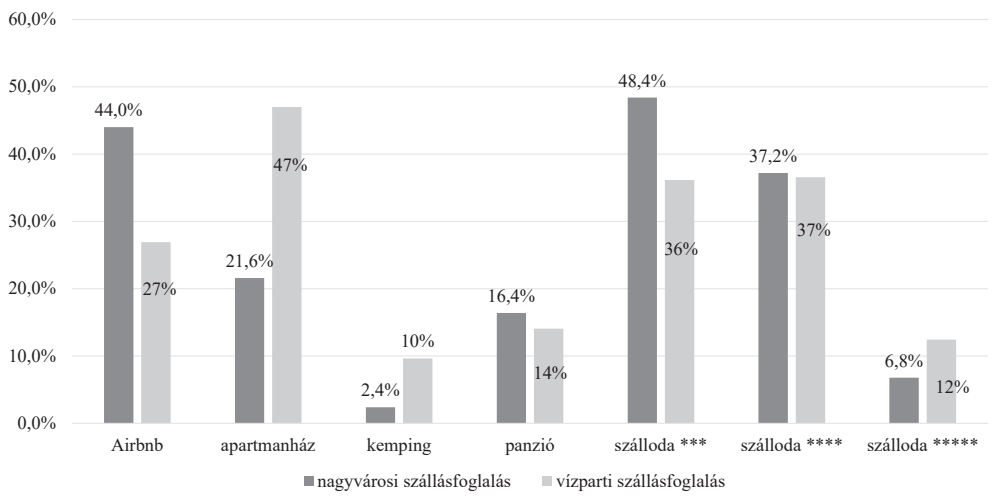

Forrás: saját szerkesztés 
A múltra vonatkozó szokások és a jövőre vonatkozó preferenciák figyelembe vételével kereszttáblák használatával - meg lehet állapítani, hogy a korábban adott szállást választóknak mekkora \% választaná a következő években is az adott szállás típust. Nagyvárosi turizmus esetén Airbnb-nek a legnagyobb a lojalitás faktora, azaz akik korábban Airbnb-t választottak, azoknak egy igen magas százaléka a jövőben is Airbnb típusú szállást választana a tervek szerint (legalábbis a következő egy-két évre vonatkozóan). Az önállóan kialakított lakásoknál $68 \%$-os az újraválasztási arány, a lakott lakásoknál 76\%, míg a megosztott szoba igénybevételnél 88\%-os azoknak az aránya, akik a jövőben is ezt a típusú szállást választanák. Ezek után jönnek a 3 csillagos (67\%), majd a 4 csillagos szállodák (61\%), utána a panziók (36\%), az 5 csillagos szállodák (34\%), és az apartmanházak (30\%). Végezetül jönnek a kempingek, ahol csak a korábbi kempinglakók 12\%-a tervezi, hogy a következő egy-két évben is kempinget választana. A vizparti szállásokra vonatkozóan eltérőek a lojalitási arányok, az Airbnb-t már igénybe vevők közül 69\%-a gondolja úgy, hogy a jövőre vonatkozóan is Airbnb-t venne igénybe (önálló lakásra vonatkoztatva), míg a szállodáknál $50 \%$ feletti viszszatérési hajlandóság van. A kempingezők 35\%-a a következő egy-két évben is igénybe szeretne venni kempinget, míg a panzióban megszállók 25\%-a tervezi, hogy a újra panzióban szálljon meg.

Ezek után elemeztük, hogy az emberek mekkora hányada tervezi az Airbnb szállásfoglalást a következő egy-két évben, kiegészítve azzal a dimenzióval, hogy az elmúlt néhány évben mely típusú szállásokat választották. Itt is különbséget teszünk a nagyvárosi és a vízparti szállásfoglalások között. A nagyvárosi szállásfoglalás esetén a panziót korábban foglalók 49\%-a és az apartmanházat foglalók 47\%-as gondolkozik Airbnb foglalásban a jövőre vonatkozóan, utána jönnek a kempingezök (41\%), valamint a három, négy és ötcsillagos szállodák $(41 \%, 38 \%, 39 \%)$ Ezen magas szándékarányok alapján valószínüsíthető, hogy a jövőre vonatkozóan komoly verseny várható a szállodák, szállodaláncok és az Airbnb között. A vízparti szállások esetén kicsit alacsonyabbak az Airbnb választás arányai (többek között ezért is lett szétválasztva a két típusú utazási irány). A korábban panziót foglalók 32\%-as és az apartmanházat foglalók $30 \%$-a, a kempingezők $26 \%$-a jelölte meg, hogy a jövőre vonatkozóan tervez Airbnb szállást igénybe venni. A szállodai szállásokat igénybe vevők 21\%-26\%-a gondolkozik Airbnb-ben a szállodai csillagok számától függően.
Ahogy láttuk, az Airbnb iránti lojalitás magasabb, mint a többi szállástípusé, ennek okait a következőkben elemezzük. Vizsgáltuk a fogyasztói attitüdöket, kerestük azokat az okokat, amelyek miatt az utazók kedvelik, és emiatt választják is az adott szállástípust. A kutatás keretében az Airbnb, illetve a szállodák iránt választási okokat vizsgáltuk. Az Airbnb esetén egyértelmüen a kedvező ár/ érték arányt jelölték meg az emberek, mint legfontosabb szállásválasztási okot. 5 fokozatú Likert skálán 4,4-es értéket adtak ennek a szempontnak, ahol az 5-ös érték mutatta, hogy az adott tényezőt nagyon fontosnak tartja a válaszadó Airbnb szállásválasztás esetén. Ezután sorrendben a választási okok, preferenciák: önálló lakás több szobával $(3,6)$, pozitív (korábbi) tapasztalatok $(3,4)$, fözési lehetöség $(3,3)$, magánlakás egyedisége $(3,1)$, valamint helyiekkel való találkozás lehetősége (3), az érdekesség (3) és az a tény, hogy nem kell alkalmazkodni a szállodai szabályokhoz (3). Szállodai választás esetén is felsoroltuk a legjellemzőbb választási okokat, itt azonban hangsúlyozni kell, hogy a kérdőív felépítéséből is adódóan a válaszadók az Airbnb-vel való összehasonlítást is figyelembe vették a válaszadók a szállodai preferenciák kitöltésénél. Eredményül kaptuk, hogy szállodát leginkább a biztonság $(3,8)$, a kiszámíthatóság $(3,8)$ és az étkezési lehetöségek $(3,9)$ miatt választják az utazók, ezen okokat a válaszadók több, mint $60 \%$-a fontosnak vagy nagyon fontosnak tartja. A wellnesst $(3,5)$, a napi takarítást, rendrakást $(3,1)$, valamint a $0 / 24$ órás recepciós szolgáltatást $(3,1)$ kevésbé ítélték meg fontosnak a válaszadók.

A fogyasztói attitüd kérdéseket alapul véve együtt is megvizsgáltuk az Airbnb és a szállodai kérdéseknél megadott válaszokat, és először faktoranalízist végeztünk. A külföldre utazó szálláskeresőknél a válaszok alapján egy faktort alkotott az Airbnb-re jellemző szolgáltatások iránti attitűd válaszok, és egy másik faktort alkotott a szállodai szolgáltatásokra felsorolt jellemzők irányába mutatott hozzáállás. Mindez azt jelenti, hogy a megkérdezetteknek egyhangúan van véleményük a szállodákról, szállodai szolgáltatásokról, és ettől függetlenül van egy véleményük az Airbnb-röl, és ezek két külön dimenzióba csoportosulnak. A fogyasztói attitüdre vonatkozó kérdéseket egyesével is megvizsgáltuk, hogy egy típusú jellemzőre adott válaszok hogyan korrelálnak egy másik jellemzőre adott válaszokkal. Az Airbnb jellegü preferencia kérdések korrelálnak egymással, egyegy kérdéspárnál a korreláció jellemzően közepesen erős vagy erős összefüggést mutat. Példaként meg lehet említeni, hogy akik számára a magánlakás egyedisége vonzó, azok számára szintén fontos 
a helyiekkel való találkozás lehetősége $(\mathrm{R}=0,492$, $\mathrm{p}=0,000, \mathrm{~N}=202$ ). Akik számára fontos, hogy önálló lakásban lehessen több különálló szobával, azok számára a főzési lehetőség szintén nagyon fontos $(\mathrm{R}=0.601, \mathrm{p}=0,000, \mathrm{~N}=225)$. Ugyanez igaz a szállodai szolgáltatásoknál megkérdezett attitűd kérdéspároknál is, a preferenciák közepesen erősen vagy erősen korrelálnak egymással. Példaként meg lehet említeni, hogy akinek fontos a 0per24-es recepció, azok számára fontos a szállodai szolgáltatásként feltüntetett napi szobatakarítás $(\mathrm{R}=0,576$, $\mathrm{p}=0,000, \mathrm{~N}=231)$ vagy a biztonság $(\mathrm{R}=0,471$, $\mathrm{p}=0,000, \mathrm{~N}=236$ ). Ezzel szemben nincs szignifikáns korrelációs összefüggés az Airbnb és a szállodai jellemzök között, még akkor sem, ha egyenként vizsgáljuk meg az attitüd kérdéseket. Mindez azt jelenti, hogy az, hogy miként itél meg valaki a szállodai szállást, abból nem lehet arra következtetni, hogy mi a véleménye az Airbnb-röl.

Végezetül az emberek nyitottságát vizsgáltuk az Airbnb-n keresztül nyújtott, helyi lakosok által kínált érdekes programokra (városnézés, fözőiskola, fényképezés stb.). A válaszadók 4\%-a már vett igénybe ilyen jellegủ szolgáltatást, és közel 50\%-uk nyitott rá, amely igen magas százalék-arány annak ismeretében, hogy ezt a típusú szolgáltatást az Airbnb mindössze néhány évvel ezelőtt indította el.

\section{ÖSSZEFOGLALÁS}

Tanulmányunkban a digitális technológia fejlődésének köszönhetően kialakult új üzleti modellnek, a sharing economy-nak, és ezen belül az Airbnbnek a térnyerését mutattuk be, illetve a magyarországi lakosok szállásválasztási szokásait, preferenciát vizsgáltuk. A szállásfoglalási piacon az elmúlt években komoly versenyhelyzet alakult ki, az Airbnb egyre nagyobb teret nyert. Az Airbnb piacrészesedése Európában 5 és $20 \%$ között van, függően attól, hogy adott ország jogszabályai mennyire korlátozzák vagy támogatják magánszemélyek rövid távú lakás kiadását (Kaszás 2018). Új trendként megfigyelhető, hogy egyre nagyobb igény van az egyedi, autentikus tapasztalatokra, megnövekedett az emberek mobilitása, igény van a személyre szabott ajánlatokra és az élményekre. Az Airbnb épp ezeket a társadalmi trendeket táplálja és/vagy elégíti ki, ezáltal komoly versenyhelyzetet teremt a szállodáknak.
Kutatásunkban arra kerestük a választ, hogy a magyarországi lakosok, akik rendszeresen utaznak külföldre, szállásfoglalásuk esetén mit választanak, milyen preferenciájuk van, és az Airbnb megjelenésével változik-e a szállásfoglalási szokásuk. Eredményül azt kaptuk, hogy a külföldre utazók 93\%-a már hallott az Airbnb-ről, 42\%-uk már foglalt is szállást az Airbnb-n keresztül. A múltbeli szokások és jövőbeli szállásválasztási preferenciák vizsgálatánál megállapítottuk, hogy az Airbnb-t már korábban használók a leglojálisabbak az Airbnbhez, azon utazók, akik már igénybe vettek Airbnb-t a múltban, azok közül legalább 68\%-uk a jövőben újraválasztaná ezt a típusú szállást. További megállapításunk, hogy az Airbnb választási hajlandóság azon utazók között a legmagasabb (az Airbnb-t már használók után), akik a múltban panzióban vagy apartmanházban laktak, és utána jönnek a szállodában lakók, de még ott is viszonylag magas, közel 40\%-os a választási hajlandóság a jövőre vonatkozóan. Az Airbnb-t az utazók leginkább a kedvezö ár/érték arány, a több szobával rendelkezö, önálló lakás bérlése, illetve a főzési lehetőség miatt választják az utazók. A szállodákat ezzel szemben a biztonság, a kiszámíthatóság és a szállodai étteremben elérhető reggeli és vacsora miatt választják a legtöbben.

Összességében elmondható, hogy az Airbnb térnyerése töretlen, kutatásunk is megerősíti, hogy az utazó emberek többsége nyitott a peer-to-peer jellegü gazdaság által nyújtott szolgáltatások igénybe vételére. Látható, hogy az online platformot üzemeltető Airbnb folyamatosan fejlődik, tágítja az elérhető szolgáltatások körét, és az elmúlt években egyre tudatosabban építi a luxus és az élményszerủ szolgáltatások kínálatát, ezzel elérve azt, hogy már nemcsak brandben és kommunikációban, hanem a szolgáltatások valódi igénybe vételénél is megtapasztalhatják az Airbnb-zők az élményszerủ és magas színvonalú kiszolgálást. 


\section{HIVATKOZÁSOK}

Airbnb Press Room (2019), https://press.airbnb.com/ en-uk/fast-facts/

Bardhi F., Eckhard G. M. (2012), ”Access-based consumption - The case of car sharing", Journal of Consumer Research, 394 881-98 DOI: https:// doi.org/10.1086/666376

Benner, K. (2017), Inside the hotel industry's plan to combat Airbnb, https://www.nytimes. com/2017/04/16/technology/inside-the-hotel-industrys-plan-to-combat-airbnb.html, (Letöltve: 2019.07.27.)

Botsman, R., Rogers, R. (2010), What's mine is yours - How collaborative consumption is changing the way we live, Harper Business

Buda G. - Lehota J. (2017), „Az internetalapú közösségi gazdálkodás formái”, Gazdaság és Társadalom, 9 2, DOI: https://doi.org/10.21637/ gt.2017.2.02.

Buda G. - Pethes B. - Karajánnisz M. - Lehota J. (2018), "Hungarian consumers' attitude to accomodation sharing service", Proceedings, 16th International Conference On Management, Enterprise and Benchmarking, 2018, P. Szikora (Ed.), Óbuda University, Budapest, ISBN 978963-449-097-5

Dogru, T., Pekin, O. (2017), "What do guests value most in Airbnb accommodations? An application of the hedonic pricing approach", Boston Hospitality Review. https://www.bu.edu/ bhr/2017/06/07/airbnb-guest-pricing-value/ (Letöltve: 2019.07.27.)

Dolnicar, S. (2017), "Unique Features of Peerto-Peer Accommodation Networks", in S Dolnicar, Peer-to-Peer Accommodation Networks: Pushing the Boundaries, Oxford: Goodfellow Publishers, 1-14 DOI: https://dx.doi. org/10.23912/9781911396512-3599,

Dudás G. - Boros L. (2019), „A közösségi gazdaság (sharing economy) definiálásának dilemmái”, Tér és Társadalom, 33 1, 107-30 DOI: https:// doi.org/10.17649/tet.33.1.3058

EB (2016), A közösségi gazdaságra vonatkozó európai menetrend. A Bizottság közleménye az Európai Parlamentnek, a Tanácsnak, az Európai Gazdasági és Szociális Bizottságnak és a Régiók Bizottságának. https://eur-lex.europa. eu/legal-content/HU/TXT/PDF/?uri=CEL$\mathrm{EX}: 52016 \mathrm{DC} 0356 \&$ from $=\mathrm{HU}$ (Letöltve: 2019.07.27.)

FastCompany (2012), Most innovative companies 2012, https:/www.fastcompany.com/most-innovative-companies/2012 (Letöltve: 2019.07.27.)

Frenken, K., Meelen, T., Arets, M., van de Glind, P. (2015), "Smarter Regulation for the Sharing Economy." An article lead - produced by Koen Frenken, Chair of Innovation Studies at the Copernicus Institute of Sustainable Development at Utrecht University, https:/www.theguardian. com/science/political-science/2015/may/20/ smarter-regulation-for-the-sharing-economy (Letöltve: 2019.07.27.)

Friedman, T. L. (2013), "Welcome to , sharing economy", The New York Times,

http://www.nytimes.com/2013/07/21/opinion/sunday/friedman-welcome-to-the-sharing-economy. html Letöltve: 2019.07.27.)

Gansky, L. (2011), Mesh vállalkozások - miért a megosztásra épülő üzleteké a jövő? HVG könyvek Kiadó

Guttentag D. A. - Smith, S. L. J. (2017), ”Assessing Airbnb as a disruptive innovation relative to hotels: substitution and comparative performance expectations", International Journal of Hospitality Management, 64 1-10 DOI: https:// doi.org/10.1016/j.ijhm.2017.02.003

Guttentag, D. A., Smith, S. L. J., Potwarka, L., Havitz M. (2017), Why Tourists Choose Airbnb? A Motivation-based Segmentation Study, Journal of Travel Research, 57 1, 1-18 DOI: https://doi. org/10.1177/00472875176969

Hilton Worldwide Holdings (2019), Q4 2018 Earning Calls, https://ir.hilton.com/ /media/ Files/H/Hilton-Worldwide-IR-V3/quarterly-results/2019/hlt-4q18-transcript-02142019.pdf (Letöltve: 2019.07.27.)

Jancsik A. - Michalkó B. - Csernyik M. (2018), „Megosztás megosztottság nélkül - az Airbnb és a budapesti szálláshelypiac alakulása", Közgazdasági Szemle, LXV március, 259-86

Kam Fung So, K., Oh, H., Min S. (2018), ”Motivation and constraints of Airbnb consumers: findings from a mixed-methods approach", Tourism Management, 67 August, 224-36 DOI: https:// doi.org/10.1016/j.tourman.2018.01.009

Kaszás F. (2018), Airbnb stays in Budapest increased by 35 percent last year, https://hungarytoday.hu/ airbnb-stays-in-budapest-increased-by-35-percent-last-year/

Mody, M., Gomez, M (2018), ”Airbnb and the Hotel Industry. The past, present, and future of sales, marketing, branding and revenue management", Boston Hospitaly Review in Business Practices, Fall 2018; https://www.bu.edu/bhr/2018/10/31/ airbnb-and-the-hotel-industry-the-past-presentand-future-of-sales-marketing-branding-andrevenue-management/ (Letöltve: 2019.07.27.)

Mody, M., Suess C., Dogru, T. (2018), ’Not in my backyard? Is the anti-Airbnb discourse truly warranted?" Annals of Tourist Research, 74C, 198-203 https:/www.researchgate.net/publication/326695883_Not_in_my_backyard Is the anti-Airbnb discourse truly_warrante $\bar{d}$ (Letöltve: 2019.07.27.)

Muñoz, P. and Cohen, B. (2017), "Mapping out the sharing economy: A configurational approach to sharing business modeling", Technological Forecasting and Social Change, DOI: https://doi. org/10.1016/j.techfore.2017.03.035

Tussyadiah, I. (2014), "An Exploratory Study on Drivers and Deterrents of Collaborative Consumption in Travel", Information and Communi- 
cation Technologies in Tourism 2015, Proceedings of the International Conference in Lugano, Switzerland, February 3-6, 2015 817-30 DOI: https://doi.org/10.1007/978-3-319-14343-9_59

Walsh, B. (2011), Today's smart choice: Dont't Own. Share, Time, 10 ideas that will change the world, http://content.time.com/time/specials/packages/ article/0,28804,2059521_2059717_2059710,00. html (Letöltve: $2019.07 . \overline{2} 7$.)

Zervas, G., Proserpio, D., Byers, J. W. (2017), ’The rise of the sharing economy: estimating the impact of Airbnb on the hotel industry", Journal of Marketing Research, 54 5, 687-705 DOI: https://doi.org/10.1509/jmr.15.0204

Buda Gabriella, PhD hallgató buda.gabriella@t-systems.hu

Dr. habil Lehota József DSc, egyetemi tanár lehota.jozsef@gtk.szie.hu

Szent István Egyetem Gazdaság- és Társadalomtudományi Kar

Üzleti Tudományok Intézete

\section{Booking preferences of tourists - Traditional commercial accommodations or Airbnb?}

\section{THE AIMS OF THE PAPER}

As a result of the digital revolution, new socio-economic trends can be observed, one such new phenomenon is sharing economy. One of the emblematic examples of this peer-to-peer economic model is Airbnb, which, 11 years after its foundation, is now one of the most important companies in the accommodation market and has become a major competitor to the most renowned hotel chains. In our study, we are focusing at consumers - in this case, those who travel abroad from Hungary - who are familiar with and open to Airbnb, and what are their preferences.

\section{METHODOLOGY}

In our online questionnaire survey, we asked 250 Hungarian residents who travel abroad. The sample is overrepresented in women with higher education in Budapest. During the data analysis, we used the method of cross-table, correlation and factor analysis.

\section{MOST IMPORTANT RESULTS}

$93 \%$ of those traveling abroad have already heard of Airbnb. $42 \%$ have already taken Airbnb service, further $36 \%$ of the respondents are open to the service. Based on previous choices and future preference testing, we found that Airbnb has the highest loyalty factor. The most endangered segment is the former apartment and boarding house users, who are presumably switching to Airbnb in 50\%, and nearly $40 \%$ of former hotel room users plan to use (also) Airbnb in the future if they are looking for accommodation in metropolitan areas. Further result in terms of consumer attitudes is that Airbnb is chosen by travelers for the best value for money, for renting the entire flat with multiple rooms, and for cooking possibilities. In contrast, the hotels are chosen by most people for safety, trustiness and breakfast's and dinner's availability at the hotel restaurant.

\section{RECOMMENDATIONS}

Further research is worth examining the threat of changing consumer preferences for traditional accommodation, the degree of competition between different types of commercial accommodation and Airbnb, the factors that different types of accommodation can increase consumers' loyalty.

Keywords: sharing economy, Airbnb, hotel, consumer attitudes, tourism The research was supported by the Ministry of Human Resources under the New National Excellence Program (ÚNKP). 